\title{
Organometallic Compounds of the Lanthanides 182 [1]. Calcium and Neodymium Complexes Containing the dpp-BIAN Ligand System: Synthesis and Molecular Structure of $\left[(\text { dpp-BIAN)CaI(THF })_{2}\right]_{2}$ and $\left[(\mathrm{dpp}-\mathrm{BIAN}) \mathrm{NdCl}(\mathrm{THF})_{2}\right]_{2}$
}

\author{
Herbert Schumann $^{\mathrm{a}}$, Markus Hummert ${ }^{\mathrm{a}}$, Anton N. Lukoyanov ${ }^{\mathrm{b}}$, Valentina A. Chudakova ${ }^{\mathrm{b}}$, \\ and Igor L. Fedushkin ${ }^{b}$ \\ ${ }^{a}$ Institut für Chemie, Technische Universität Berlin, Straße des 17. Juni 135, D-10623 Berlin, \\ Germany \\ b G. A. Razuvaev Institute of Organometallic Chemistry, Russian Academy of Sciences, \\ Tropinina 49, 603950 Nizhny Novgorod, GSP-445, Russia \\ Reprint requests to Prof. Dr. H. Schumann. Fax: +49 3031422168. \\ E-mail: schumann@chem.tu-berlin.de \\ Z. Naturforsch. 2007, 62b, 1107 -1111; received April 25, 2007

\begin{abstract}
Oxydation of (dpp-BIAN)Ca(THF $)_{4}$ with 0.5 equiv. of $\mathrm{I}_{2}$ in THF yields [(dpp-BIAN)CaI(THF $\left.)_{2}\right]_{2}$ (1). A corresponding neodymium compound [(dpp-BIAN)NdCl(THF $\left.)_{2}\right]_{2}(2)$ has been obtained by reaction of (dpp-BIAN)Na $\mathrm{Na}_{2}$ with $\mathrm{NdCl}_{3}$ in THF. The X-ray single crystal structure analyses show respective halides. The chelating dpp-BIAN ligand acts as a radical anion in the $\mathrm{Ca}^{2+}$ complex $\mathbf{1}$ and
\end{abstract} \\ 1 and $\mathbf{2}$ to be isostructural dimers containing octahedrally coordinated metal atoms bridged by the \\ as a dianion in the $\mathrm{Nd}^{3+}$ complex $\mathbf{2}$, respectively.
}

Key words: Neodymium, Calcium, Diimine Ligands, X-Ray Structure

\section{Introduction}

The metal ion-mediated condensation of acenaphthene quinone with aromatic amines producing acenaphthene-1,2-diimines (Ar-BIAN) has been reported by Matai [2] in 1960 and by Lixandru in 1967 [3]. With the exception of the synthesis of (BIAN)PtCl ${ }_{2}\left(\mathrm{C}_{2} \mathrm{H}_{4}\right)$ by Maresca et al. in 1975 [4], it took about 30 years until the particular suitability of Ar-BIAN systems as chelating ligands for metals has been recognized. The first results have been reported by van Asselt and Elsevier in the early 1990ies [5]. In the following years, numerous $d$-block metal complexes with different Ar-BIAN ligands have been described in more than 150 papers, and it turned out that many of the respective late transition metal complexes serve well as catalysts for a variety of organic transformations [6]. In contrast, investigations of the chemistry of $s$ - and $p$-block element complexes with Ar-BIAN as ligand started only recently [7], and Ar-BIAN complexes of $f$-block metals are quite unknown until now.

1,2-Bis[(2,6-diisopropylphenyl)imino]acenaphthene (dpp-BIAN) is the most widely used ligand of the
Ar-BIAN series. One of the remarkable features of the dpp-BIAN ligand is its ability to adopt a variety of oxidation states. dpp-BIAN can be easily reduced by alkali metals to one-, two-, three-, and four-fold negatively charged anions yielding salts of the type $(\mathrm{dpp}-\mathrm{BIAN})^{n-} \mathrm{M}_{n}{ }^{+}(\mathrm{L})_{x}(\mathrm{M}=\mathrm{Li}, \mathrm{Na} ; n=1-4 ; \mathrm{L}=$ $\mathrm{Et}_{2} \mathrm{O}, \mathrm{THF}$ ) [7b]. Alkaline earth metals reduce dppBIAN only up to the stage of the dianion producing the monomeric complexes (dpp-BIAN $)^{2-} \mathrm{M}^{2+}(\mathrm{L})_{x}$ $(\mathrm{M}=\mathrm{Mg}, \mathrm{Ca}, \mathrm{Sr}, \mathrm{Ba} ; \mathrm{L}=$ coordinating solvent $)$ [7c, 7i].

Because the alkaline earth elements and the metals of the lanthanide series show certain similarities, the latter may be called "pseudo-alkaline earth metals". First of all, the elements of these two groups represent electropositive metals with values of their electronegativity close to 1.1 . However, whereas the ionic radii of the alkaline earth elements increase from $\mathrm{Mg}$ to $\mathrm{Ba}$, the ionic radii of the lanthanide metals decrease with increasing atomic number. The ionic radii of the early lanthanide metal ions in the common oxidation state $\mathrm{Ln}^{3+}$ range from $1.032 \AA$ for $\mathrm{La}^{3+}$ to $0.983 \AA$ for $\mathrm{Nd}^{3+}$ and are close to the ionic radius of $\mathrm{Ca}^{2+}$ (1.00 $\AA$ ) [8]. In this context it has been observed that complexes of 
$\mathrm{Ca}^{2+}$ and $\mathrm{Yb}^{2+}$ ions with one and the same ligand show almost identical structural parameters [9]. This fact has been the motivation for our studies of dppBIAN complexes of the early lanthanides. In this paper we report on the synthesis of the first dpp-BIAN neodymium complex and on the result of a comparison of its molecular structure with that of an analogous calcium complex using single crystal X-ray structure analysis.

\section{Results and Discussion}

Synthesis of $\left[(\text { dpp-BIAN }) \mathrm{CaI}(\mathrm{THF})_{2}\right]_{2}(\mathbf{1})$ and [(dpp-BIAN)NdCl(THF $\left.)_{2}\right]_{2}(2)$

Addition of 0.5 equiv. of iodine to a solution of (dpp-BIAN)Ca(THF) ${ }_{4}[7 \mathrm{c}]$ in THF causes an immediate change in the color of the solution from greenbrown to cherry-red, indicative of the oxidation of the dianion [(dpp-BIAN) $]^{2-}$ in the starting calcium compound to the radical-anion [(dpp-BIAN $)]^{-{ }^{-}}$in the complex [(dpp-BIAN)CaI(THF) $\left.{ }_{2}\right]_{2}$ (1) formed (Scheme 1). The deep red crystals of the dimeric compound $\mathbf{1}$, isolated from diethyl ether in a yield of $53 \%$, melt without decomposition between 195 and $197{ }^{\circ} \mathrm{C}$ and are sensitive against moisture and air. The ESR spectrum of $\mathbf{1}$ recorded in toluene at $293 \mathrm{~K}$ shows a quintet ( $g=$ 2.00333) with coupling of the unpaired electron to the ${ }^{14} \mathrm{~N},{ }^{1} \mathrm{H}$ and ${ }^{127} \mathrm{I}$ nuclei $\left(A\left({ }^{14} \mathrm{~N}\right)=0.44(2 \mathrm{~N}) ; A\left({ }^{127} \mathrm{I}\right)=\right.$ $\left.0.05(1 \mathrm{I}) ; A\left({ }^{1} \mathrm{H}\right)=0.10(4 \mathrm{H}) \mathrm{mT}\right)$.

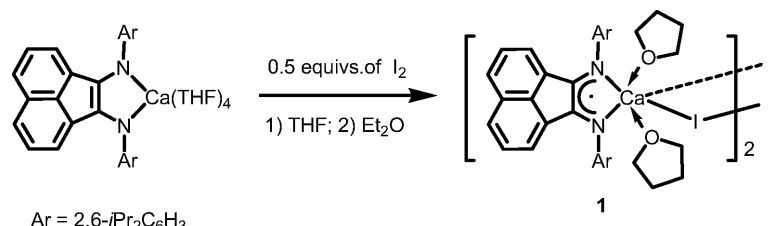

Scheme 1. Synthesis of $\mathbf{1}$.

$\mathrm{NdCl}_{3}$ reacts with the green disodium salt (dppBIAN) $\mathrm{Na}_{2}[7 \mathrm{~b}]$ in THF with formation of the complex $\left[(\mathrm{dpp}-\mathrm{BIAN}) \mathrm{NdCl}(\mathrm{THF})_{2}\right]_{2}$ (2) (Scheme 2). The reaction is connected with a change of the color of the solution from green to blue. Compound $\mathbf{2}$ crystallizes from diethyl ether as deep blue, nearly black crystals in a yield of $57 \%$. As it is the case with the blue aluminum [10] and gallium complexes [11], the color of the crystals of $\mathbf{2}$ indicates the existence of the dpp-BIAN ligand in its dianionic form. The air and moisture sensitive compound $\mathbf{2}$ melts without decomposition between 210 and $215{ }^{\circ} \mathrm{C}$. Besides diethyl ether and THF, the complex is soluble in aromatic hydrocarbons.

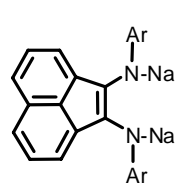

$\mathrm{Ar}=2,6-\mathrm{Pr}_{2} \mathrm{C}_{6} \mathrm{H}_{3}$

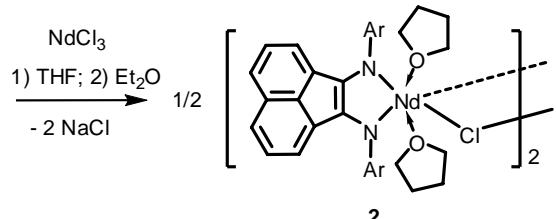

Scheme 2. Synthesis of 2.

Compounds $\mathbf{1}$ and $\mathbf{2}$ are paramagnetic, the calcium derivative due to the presence of the radical-anionic dpp-BIAN ligand and the neodymium complex due to the paramagnetism of the $\mathrm{Nd}^{3+}$ ion. For this reason, no NMR spectroscopic measurements were carried out. The complexes have been characterized by elemental analysis, IR spectroscopic investigations, and by determination of their molecular structure.

\section{Molecular structures of $\left[(\text { dpp-BIAN }) \mathrm{CaI}(\mathrm{THF})_{2}\right]_{2}$ (1) and [(dpp-BIAN)NdCl(THF $\left.)_{2}\right]_{2}(2)$}

Crystals of $\mathbf{1}$ and $\mathbf{2}$ suitable for single crystal X-ray diffraction were obtained by slow evaporation of ethereal solutions of the compounds. Both complexes are isostructural in the crystalline state. They form dimers bridged by $\mathrm{I}$ and $\mathrm{Cl}$ atoms, respectively, with crystallographic inversion centers located at the center of the line between the metal atoms (Figs. 1 and 2). The calcium and neodymium atoms are in the center of an octahedral environment formed by the two nitrogen atoms of the dpp-BIAN ligand, the oxygen atoms of the two coordinated THF molecules and the respective two bridging halogen atoms. One of the THF ligands is in a position trans to one of the nitrogen atoms of the dpp-BIAN ligand, the other one is in a trans position to one of the bridging halogen atoms. The $\mathrm{Ca}-\mathrm{O}$ distances in $\mathbf{1}(\mathrm{O}(1)-\mathrm{Ca} 2.405(3), \mathrm{O}(2)-\mathrm{Ca} 2.399(3) \AA)$ are somewhat shorter than the Nd-O distances in $2(\mathrm{O}(1)-\mathrm{Nd}$ 2.470(4), O(2)-Nd 2.525(3) $\AA$ ). On the other hand, the Ca-N distances in 1 (N(1)-Ca 2.467(4), N(2)-Ca $2.452(4) \AA$ ) are remarkably longer than the Nd-N distances in 2 (N(1)-Nd 2.345(4), N(2)-Nd 2.303(4) $\AA$ ). This fact reflects a stronger bonding of the neodymium ion to the dpp-BIAN dianion in $\mathbf{2}$ as compared to the bonding of the calcium ion to the radical-anionic dppBIAN ligand in $\mathbf{1}$. For comparison, the $\mathrm{Ca}-\mathrm{N}$ distances in (dpp-BIAN)Ca(THF) $)_{4}$ containing dpp-BIAN dianions are 2.396(2) and 2.382(2) $\AA$ [7c].

The X-ray crystallographic data confirm the "reduction state" of the dpp-BIAN ligand in $\mathbf{1}$ and $\mathbf{2}$. The changes in the population of the LUMO on going 


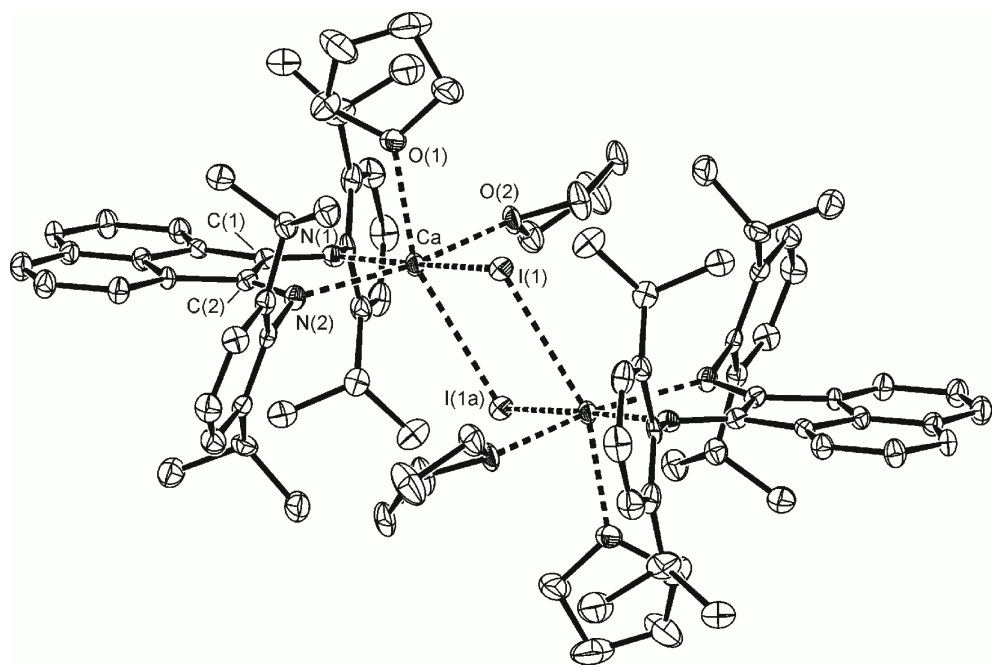

Fig. 1. ORTEP [12] presentation of the molecular structure of $\mathbf{1}$ (30\% probability ellipsoids; hydrogen atoms omitted for clarity). Selected bond lengths $(\AA)$ and angles (deg): $\mathrm{C}(1)-\mathrm{N}(1)$ 1.340(6), $\mathrm{C}(2)-\mathrm{N}(2) 1.332(5), \mathrm{C}(1)-\mathrm{C}(2) 1.456(6)$, $\mathrm{N}(1)-\mathrm{Ca} \quad 2.467(4), \quad \mathrm{N}(2)-\mathrm{Ca}$ 2.452(4), $\mathrm{O}(1)-\mathrm{Ca}$ 2.405(3), O(2)-Ca 2.399(3), Ca-I(1) 3.2079(11), Ca-I(1a) 3.1657(11); $\mathrm{O}(2)-\mathrm{Ca}-\mathrm{O}(1)$ 84.21(13), O(2)-Ca-N(2) 163.12(14), O(1)-Ca-N(2) 91.77(13), $\mathrm{O}(2)-\mathrm{Ca}-\mathrm{N}(1)$ 91.32(13), O(1)-Ca-N(1) 89.36(12), N(2)-Ca-N(1) 72.21(14), I(1)-Ca-I(1a) 79.34(3).

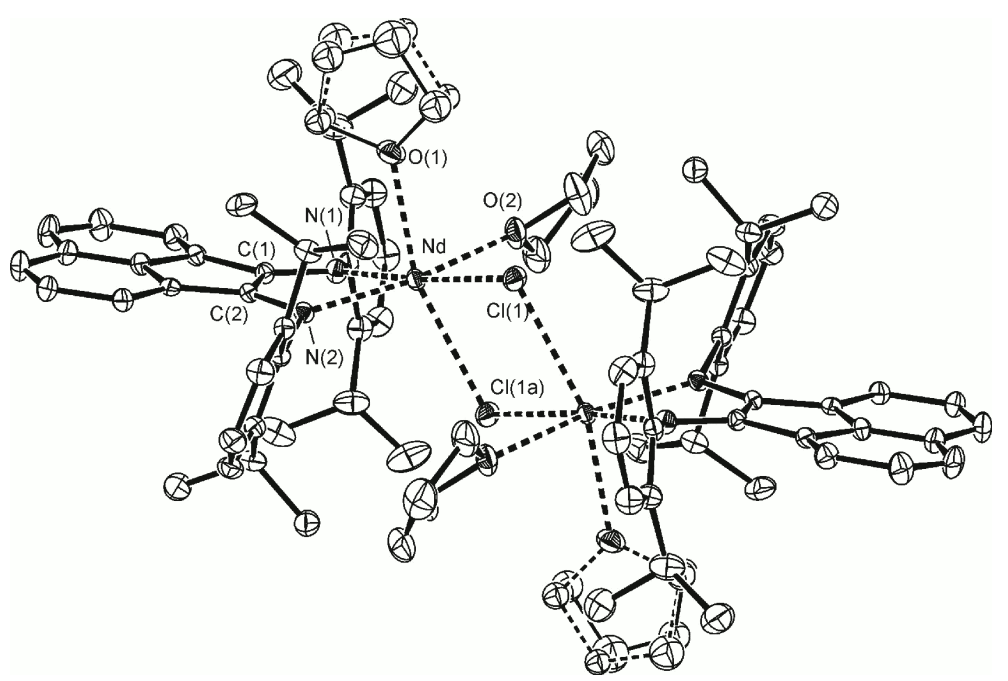

Fig. 2. ORTEP [12] presentation of the molecular structure of $\mathbf{2}(30 \%$ probability ellipsoids; hydrogen atoms omitted

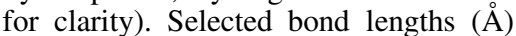
and angles (deg): $\mathrm{C}(1)-\mathrm{N}(1)$ 1.396(6), $\mathrm{C}(2)-\mathrm{N}(2) 1.396(6), \mathrm{C}(1)-\mathrm{C}(2) 1.388(6)$, $\mathrm{N}(1)-\mathrm{Nd} 2.345(4), \mathrm{N}(2)-\mathrm{Nd} 2.303(4)$, $\mathrm{O}(1)-\mathrm{Nd} \quad 2.470(4), \quad \mathrm{O}(2)-\mathrm{Nd} \quad 2.525(3)$, $\mathrm{Nd}-\mathrm{Cl}(1 \mathrm{a}) \quad 2.8184(14), \quad \mathrm{Nd}-\mathrm{Cl}(1)$ 2.8974(13); O(2)-Nd-O(1) 88.01(12), $\mathrm{O}(2)-\mathrm{Nd}-\mathrm{N}(2)$ 162.67(13), O(1)-Nd-N(2) 89.63(13), O(2)-Nd-N(1) 88.31(13), $\mathrm{O}(1)-\mathrm{Nd}-\mathrm{N}(1)$ 91.35(13), N(2)-Nd-N(1) 74.58(13), Cl(1)-Nd-Cl(1a) 75.27(4). from neutral dpp-BIAN to its radical anion and further to its dianion suggest a progressive shortening of the central $\mathrm{C}(1)-\mathrm{C}(2)$ bond associated with an increasing elongation of the $\mathrm{C}(1)-\mathrm{N}(1)$ and $\mathrm{C}(2)-\mathrm{N}(2)$ distances. Our results agree with this expectation showing that in 1 containing the dpp-BIAN radical anion, the $\mathrm{C}(1)-\mathrm{N}(1)$ and $\mathrm{C}(2)-\mathrm{N}(2)$ bonds $(1.340(6)$, $1.332(5) \AA$ ) are longer than in free dpp-BIAN (both $1.282(4) \AA$ ) [13], but shorter than in the dpp-BIAN dianion in the complex (dpp-BIAN)Ca(THF) $)_{4}(1.391(3)$ and 1.402(3) $\AA$ ) [7c]. The $\mathrm{C}(1)-\mathrm{N}(1)$ and $\mathrm{C}(2)-\mathrm{N}(2)$ distances in 2 (1.396(6) and 1.396(6) $\AA$ ) agree well with those in (dpp-BIAN)Ca(THF) $)_{4}$, thus confirming the dianionic character of the dpp-BIAN ligand in 2 .

\section{Experimental Section}

All manipulations were carried out in vacuum using standard Schlenk techniques or in an inert atmosphere. The solvents THF and $\mathrm{Et}_{2} \mathrm{O}$ were distilled from sodium/benzophenone prior to use. The IR spectra were recorded using a Bruker Vertex 70 instrument. Elemental analyses were carried out using a Perkin-Elmer Series II CHNS/O Analyzer 2400. dppBIAN [14] was prepared according to the published procedure.

\section{$\left[(\mathrm{dpp}-\mathrm{BIAN}) \mathrm{CaI}(\mathrm{THF})_{2}\right]_{2}(\mathbf{1})$}

According to the procedure described recently [7c], calcium metal granules $(5.5 \mathrm{~g}, 137 \mathrm{mmol})$ in THF $(30 \mathrm{~mL})$ were activated by $\mathrm{CH}_{2} \mathrm{I}_{2}(0.8 \mathrm{~g}, 2.98 \mathrm{mmol})$ and then treated 
Table 1. Parameters of the single crystals, data collection and structure refinement of $\mathbf{1}$ and $\mathbf{2}$.

\begin{tabular}{|c|c|c|}
\hline & 1 & 2 \\
\hline Empirical formula & $\mathrm{C}_{96} \mathrm{H}_{132} \mathrm{Ca}_{2} \mathrm{I}_{2} \mathrm{~N}_{4} \mathrm{O}_{6}$ & $\mathrm{C}_{96} \mathrm{H}_{132} \mathrm{Cl}_{2} \mathrm{~N}_{4} \mathrm{Nd}_{2} \mathrm{O}_{6}$ \\
\hline Formula wt., $\mathrm{g} \mathrm{mol}^{-1}$ & 1772.02 & 1797.44 \\
\hline Crystal size, $\mathrm{mm}^{3}$ & $0.12 \times 0.06 \times 0.05$ & $0.56 \times 0.50 \times 0.33$ \\
\hline Crystal system & monoclinic & monoclinic \\
\hline Space group & $P 2{ }_{1} / c$ & $P 2_{1} / n$ \\
\hline Z & 2 & 2 \\
\hline$a, \AA$ & $12.1519(17)$ & $15.032(5)$ \\
\hline$b, \AA$ & $18.293(3)$ & $18.056(5)$ \\
\hline$c, \AA$ & $21.451(4)$ & $16.962(5)$ \\
\hline$\beta, \operatorname{deg}$ & $100.860(13)$ & $98.404(5)$ \\
\hline$V, \AA^{3}$ & $4682.9(13)$ & $4554(2)$ \\
\hline$D_{\text {calcd }}, \mathrm{g} \mathrm{cm}^{-3}$ & 1.257 & 1.311 \\
\hline Absorp. coeff., mm ${ }^{-1}$ & 0.833 & 1.239 \\
\hline Transmission $\mathrm{min} / \max$ & $0.921 / 0.840$ & $0.74120 / 0.27834$ \\
\hline$F(000), \mathrm{e}$ & 1860 & 1876 \\
\hline $\begin{array}{l}2 \theta \text { range for data } \\
\text { collection, deg }\end{array}$ & $2.95 \leq \theta \leq 28.75$ & $1.66 \leq \theta \leq 25.00$ \\
\hline \multirow[t]{3}{*}{$h k l$-Range } & $-15 \leq h \leq 15$ & $-13 \leq h \leq 17$ \\
\hline & $-24 \leq k \leq 22$ & $-21 \leq k \leq 20$ \\
\hline & $-25 \leq l \leq 27$ & $-20 \leq l \leq 18$ \\
\hline Reflections, collected & 24316 & 28237 \\
\hline Reflections, unique & 10292 & 8012 \\
\hline$R_{\text {int }}$ & 0.082 & 0.107 \\
\hline Data/restraints/param. & $10292 / 0 / 506$ & $8012 / 19 / 501$ \\
\hline Goodness-of-Fit $\left(F^{2}\right)$ & 0.889 & 1.043 \\
\hline$R 1 / w R 2[I \geq 2 \sigma(I)]$ & $0.062 / 0.103$ & $0.050 / 0.122$ \\
\hline$R 1 / w R 2$ (all data) & $0.155 / 0.118$ & $0.066 / 0.139$ \\
\hline $\begin{array}{l}\text { Largest diff. peak and } \\
\text { hole, e } \AA^{-3}\end{array}$ & $0.87 /-0.77$ & $1.55 /-1.26$ \\
\hline
\end{tabular}

with dpp-BIAN (0.5 g, $1 \mathrm{mmol})$ in THF (50 mL). After stirring the mixture under reflux for $1 \mathrm{~h}$, it was cooled down to r.t. and the solution was decanted from excess Ca metal. To the separated solution containing (dpp-BIAN)Ca(THF) ${ }_{4}$, iodine $(0.13 \mathrm{~g}, 0.5 \mathrm{mmol})$ was added with stirring. The color of the reaction mixture changed immediately from green-brown to cherry-red. After $1 \mathrm{~h}$, the solvent was removed in vacuum. The remaining crude product was dissolved in diethyl ether $(45 \mathrm{~mL})$ and the solution was filtered off. Slow evaporation of the ether resulted in the precipitation of deep red crystals of $1(0.47$ g, $53 \%)$. M. p. $195-$ $197{ }^{\circ} \mathrm{C}$. - IR (Nujol): $v=1668$ (m), 1640 (m), 1593 (m), 1512 (s), 1410 (s), 1314 (m), 1276 (w), 1252 (m), 1221 (w), 1185 (s), 1119 (m), 1076 (w), 1030 (s), 939 (w), 926 (m), $877(\mathrm{~m}), 844$ (s), $836(\mathrm{~m}), 821(\mathrm{~m}), 803(\mathrm{w}), 787(\mathrm{~m})$, $777(\mathrm{~m}), 759(\mathrm{~m}), 751(\mathrm{~s}) \mathrm{cm}^{-1} .-\mathrm{C}_{88} \mathrm{H}_{112} \mathrm{Ca}_{2} \mathrm{I}_{2} \mathrm{~N}_{4} \mathrm{O}_{4} \times$ $2 \mathrm{Et}_{2} \mathrm{O}$ (1772.10): calcd. C 65.07, H 7.51; found C 64.85, H 7.38.

\section{$\left[(\mathrm{dpp}-\mathrm{BIAN}) \mathrm{NdCl}(\mathrm{THF})_{2}\right]_{2}$ (2)}

According to the procedure described recently [7b], dppBIAN (0.56 g, $1.12 \mathrm{mmol})$ in THF (30 mL) was added to an ampoule containing a piece of sodium $(52 \mathrm{mg}, 2.3 \mathrm{mmol})$ and the mixture was stirred at r.t. for $4 \mathrm{~h}$. To the decanted green solution of (dpp-BIAN) $\mathrm{Na}_{2}, \mathrm{NdCl}_{3}(\mathrm{THF})_{2.1}(0.45 \mathrm{~g}$, $1.1 \mathrm{mmol}$ ) was added. With precipitation of $\mathrm{NaCl}$, the color of the reaction mixture changed from green to blue. The mixture was stirred for $1 \mathrm{~h}$ at ambient temperature followed by evaporation of the solvent in vacuum. The residue was dissolved in $\mathrm{Et}_{2} \mathrm{O}(50 \mathrm{~mL})$ and the deep blue solution was filtered off from insoluble $\mathrm{NaCl}$. Slow evaporation of the solvent resulted in the precipitation of deep blue crystals of $2(0.56 \mathrm{~g}, 57 \%)$. M. p. $210-215{ }^{\circ} \mathrm{C}$. - IR (Nujol): $v=1919(\mathrm{w}), 1857(\mathrm{w}), 1791(\mathrm{w}), 1669(\mathrm{w}), 1612(\mathrm{~m})$, 1582(s), 1305(m), 1253(m), 1184(m), 1122(m), 1038(w), 916(s), 857(m), 813(m), 797(m), 767(s), 758(s), 749(s), 696(m), 683(m), 625(s), 600(w), 541(m), 512(m) $\mathrm{cm}^{-1}$. $\mathrm{C}_{88} \mathrm{H}_{112} \mathrm{Cl}_{2} \mathrm{~N}_{4} \mathrm{Nd}_{2} \mathrm{O}_{4} \times 2 \mathrm{Et}_{2} \mathrm{O}$ (1797.51): calcd. C 64.15, $\mathrm{H}$ 7.40; found C 64.79, H 7.45.

\section{Crystal structure determination}

Crystals suitable for X-ray diffraction were obtained by crystallization of $\mathbf{1}$ and $\mathbf{2}$ from diethyl ether. The data of $\mathbf{1}$ were collected using an Xcalibur S Sapphire diffractometer (Oxford Diffraction) at $150 \mathrm{~K}$, the data of $\mathbf{2}$ using a Siemens SMART CCD diffractometer (graphitemonochromated $\operatorname{Mo} K_{\alpha}$ radiation, $\lambda=0.71070 \AA$ ) and $\omega$ scans at $173 \mathrm{~K}$. The structures were solved by Direct Methods using SIR97 [15] or SIR2004 [16] and were refined with SHELXL-97 [17] on $F^{2}$ using all reflections. All nonhydrogen atoms were refined anisotropically and the carbonbound hydrogen atoms were placed in calculated positions using a riding model. For 2, SADABS [18] was used to perform area-detector scaling and absorption corrections. The important parameters of the single crystals, the data collection and the refinement of the structures are listed in Table 1.

CCDC 641588 (1) and 641589 (2) contain the supplementary crystallographic data for this paper. These data can be obtained free of charge from The Cambridge Crystallographic Data Centre via www.ccdc.cam.ac.uk/data_request/ cif.

\section{Acknowledgement}

This work was supported by the Deutsche Forschungsgemeinschaft (SPP "Lanthanoidspezifische Funktionalitäten in Molekül und Material"), the Fonds der Chemischen Industrie and the Russian Foundation for Basic Research.
[1] Part 181: H. Schumann, D. M. M. Freckmann, S. Schutte, S. Dechert, M. Hummert, Z. Anorg. Allg. Chem. 2007, 633, 888.
[2] I. Matei, T. Lixandru, E. Comanita, Acad. Rep. Populare Romine, Filiala Iasi, Studii Cercetari Stiint. Chim 1960, 11, 281. 
[3] I. Matei, T. Lixandru, Buletinul Institutului Politehnic din Iasi 1967, 13, 245.

[4] L. Maresca, G. Natile, L. Cattalini, Inorg. Chim. Acta 1975, 14, 79 .

[5] a) R. van Asselt, E. E. C. G. Gielens, R. E. Rulke, C. J. Elsevier, J. Chem. Soc., Chem. Commun. 1993, 1203; b) R. van Asselt, E.E.C.G. Gielens, R.E. Rulke, K. Vrieze, C. J. Elsevier, J. Am. Chem. Soc. 1994, 116, 977; c) R. van Asselt, E. Rijnberg, C. J. Elsevier, Organometallics 1994, 13, 706; d) R. van Asselt, C. J. Elsevier, W. J. J. Smeets, A. L. Spek, Inorg. Chem. 1994, 33, 1521; e) R. van Asselt, C. J. Elsevier, Organometallics 1994, 13, 1972; f) R. van Asselt, C. J. Elsevier, W. J. J. Smeets, A. L. Spek, R. Benedix, Rec. Trav. Chim. Pays-Bas 1994, 113, 88.

[6] a) R. van Asselt, C. J. Elsevier, Tetrahedron 1994, 50, 323; b) S. Tollari, S. Cenini, F. Ragaini, L. Cassar, J. Chem. Soc., Chem. Commun. 1994, 1741; c) L. K. Johnson, Ch. M. Killian, M. Brookhart, J. Am. Chem. Soc. 1995, 117, 6414; d) S. Cenini, F. Ragaini, St. Tollari, D. Paone, J. Am. Chem. Soc. 1996, 118, 11964; e) J. H. Groen, J. G. P. Delis, P. W. N. M. van Leeuwen, K. Vrieze, Organometallics 1997, 16, 68; f) R. van Belzen, H. Hoffmann, C. J. Elsevier, Angew. Chem. 1997, 109, 1833; Angew. Chem. Int. Ed. 1997, 36, 1743; g) R. van Belzen, R. A. Klein, H. Kooijman, N. Veldman, A. L. Spek, C. J. Elsevier, Organometallics 1998, 17, 1812; h) E. Shirakawa, H. Yoshida, Y. Nakao, T. Hiyama, J. Am. Chem. Soc. 1999, 121, 4290; i) M. W. van Laren, C. J. Elsevier, Angew. Chem. 1999, 111, 3926; Angew. Chem. Int. Ed. 1999, 38, 3715; j) F. Ragaini, S. Cenini, St. Tollari, G. Tummolillo, R. Beltrami, Organometallics 1999, 18, 928; k) F. Ragaini, P. Sportiello, S. Cenini, J. Organomet. Chem. 1999, 577, 283; 1) S. D. Ittel, L. K. Johnson, M. Brookhart, Chem. Rev. 2000, 100, 1169; m) D. B. Llewellyn, D. Adamson, B. A. Arndtsen, Org. Lett. 2000, 2, 4165; n) F. Ragaini, S. Cenini, E. Borsani, M. Dompé, E. Gallo, Organometallics 2001, 20, 3390; o) G. A. Grasa, A. C. Hillier, S. P. Nolan, Org. Lett. 2001, 3, 1077; p) G. A. Grasa, R. Singh, E. D. Stevens, S. P. Nolan, J. Organomet. Chem. 2003, 687, 269.

[7] a) H. A. Jenkins, C.L. Dumaresque, D. Vidovic, J.A.C. Clyburne, Can. J. Chem. 2002, 80, 1398; b) I. L. Fedushkin, A. A. Skatova, V. A. Chudakova, G. K. Fukin, Angew. Chem. 2003, 115, 3416; Angew. Chem. Int. Ed. 2003, 42, 3294; c) I. L. Fedushkin, A. A. Skatova, V. A. Chudakova, G. K. Fukin, S. Dechert, H. Schumann, Eur. J. Inorg. Chem. 2003, 3336; d) I. L. Fedushkin, A. A. Skatova, V. A. Chudakova, V. K. Cherkasov, G. K. Fukin, M. A. Lopatin, Eur. J. Inorg. Chem. 2004, 388; e) R. J. Baker, C. Jones, M. Kloth and D. P. Mills, New J. Chem. 2004, 28, 207; f) I. L. Fedushkin, A. A. Skatova, V. A. Chudakova, N. M.
Khvoinova, A. Yu. Baurin, S. Dechert, M. Hummert, H. Schumann, Organometallics 2004, 23, 3714; g) I. L. Fedushkin, N. M. Khvoinova, A. Yu. Baurin, G. K. Fukin, V. K. Cherkasov, M. P. Bubnov, Inorg. Chem. 2004, 43, 7807; h) I. L. Fedushkin, V. A. Chudakova, A. A. Skatova, N. M. Khvoinova, Yu. A. Kurskii, T. A. Glukhova, G. K. Fukin, S. Dechert, M. Hummert, H. Schumann, Z. Anorg. Allg. Chem. 2004, 630, 501; i) I. L. Fedushkin, A. G. Morozov, O. V. Rassadin, G. K. Fukin, Chem. Eur. J. 2005, 11, 5749; j) H. Schumann, M. Hummert, A. N. Lukoyanov, I. L. Fedushkin, Organometallics 2005, 24, 3891; k) P. J. Bailey, C. M. Dick, S. Fabre, S. Parsons, L. J. Yellowlees, Dalton Trans. 2006, 1602; 1) G. Reeske, C. R. Hoberg, N. J. Hill, A. H. Cowley, J. Am. Chem. Soc. 2006, 128, 2800; m) N. J. Hill, G. Reeske, J. A. Moore, A. H. Cowley, Dalton Trans. 2006, 4838.

[8] R. D. Shannon, Acta Crystallogr. Sect. A 1976, 32, 751.

[9] a) R. A. Williams, T.P. Hanusa, J.C. Huffman, Organometallics 1990, 9, 1128; b) I. L. Fedushkin, T. V. Petrovskaya, M. N. Bochkarev, S. Dechert, H. Schumann, Angew. Chem. 2001, 113, 2540; Angew. Chem. Int. Ed. 2001, 40, 2474; c) F. Weber, H. Sitzmann, M. Schultz, C.D. Sofield, R. A. Anderson, Organometallics 2002, 21, 3139; d) H. Schumann, S. Schutte, H. J. Kroth, D. Lenz, Angew. Chem. Int. Ed. 2004, 43, 6208.

[10] A. N. Lukoyanov, I. L. Fedushkin, H. Schumann, M. Hummert, Z. Anorg. Allg. Chem. 2006, 632, 1471.

[11] A. N. Lukoyanov, S. Y. Ketkov, M. Hummert, H. Schumann, Chem. Eur. J., in press.

[12] A.L. Spek, Platon, A. Multipurpose Crystallographic Tool, Utrecht University, Utrecht (The Netherlands) 2000. See also: A. L. Spek, J. Appl. Cryst. 2003, $36,7-13$.

[13] I. L. Fedushkin, V. A. Chudakova, G. K. Fukin, S. Dechert, M. Hummert, H. Schumann, Russ. Chem. Bul. Int. Ed. 2004, 53, 2744.

[14] A. A. Paulovicova, U. El-Ayaan, K. Shibayama, T. Morita, Y. Fukuda, Eur. J. Inorg. Chem. 2001, 2641.

[15] A. Altomare, M. C. Burla, M. Camalli, G. L. Cascarano, C. Giacovazzo, A. Guagliardi, A. G. G. Moliterni, G. Polidori, R. Spagna, SiR97, J. Appl. Crystallogr. 1999, 32, 115-119.

[16] M. C. Burla, R. Caliandro, M. Cavalli, B. Carrozzini, G. L. Cascarano, L. de Caro, C. Giacovazzo, G. Polidori, R. Spagna, SIR2004, J. Appl. Cryst. 2005, 38, $381-388$.

[17] G. M. Sheldrick, SHELXL-97, Program for the Refinement of Crystal Structures, University of Göttingen, Göttingen (Germany) 1997.

[18] G. M. Sheldrick, SADABS, Program for Empirical Absorption Correction of Area Detector Data, University of Göttingen, Göttingen (Germany) 1997. 